\title{
NOTES AND STUDIES
}

\section{PAPIAS ON THE AGE OF OUR LORD.}

In a former article in this Journal (July I907, vol. viii p. 590) I have argued that certain calculations which placed the Birth, Baptism, and Passion of Christ in the years 9, 46, and 58 were made by Hippolytus in his youth, with the help of the imperial chronology of Tertullian, and that they were based on no ancient tradition. But it appeared that Hippolytus must have appealed to tradition for some other part of the statements attributed to him by the independent witness of Alexander of Jerusalem, Epiphanius, and Annianus. From their confused testimony it would seem that he based his assertions on 'tradition' from 'one who had known the Apostles'. This in a disciple of Irenaeus suggests that he had used the book of Papias. The points which might with some probability be supposed to be grounded on Papias were found to be three only: (a) that the Annunciation took place on the same day of the week as the Resurrection and the Creation of light (Alexander and Annianus); (b) that Christ was seven months in the womb (Epiphanius, from 'tradition') ; (c) possibly the two lines of Dom Morin's fragment of Alexander :-1

\section{Feria vj annuntiatus, feria $j$ natus,}

feria v baptizatus, feria vj passus,

provided that we harmonize this with $a$, by conjecturing feria $j$ annuntiatus, feria vj natus.

I added that these three points are to be found together in a fragment of Victorinus, which I had on independent grounds recognized as probably dependent on Papias, perhaps verbally.

\section{$\S \mathrm{I}$. Hippolytus and a fragment of Victorinus.}

I quote the passage of Victorinus's fragment De fabrica mundi from the only $\mathrm{MS}^{2}$ :-

fol. $72 b$ 'Ecce 1 septem cornula (cornua) agnuli, ' septem oculos di, ${ }^{3}$ septem oculi stagnei (agnuli), septem oculi, 'septem sps,, ${ }^{5}$ septem faces ardentes ante thronum dei, ${ }^{6}$ septem candelabra aurea, 7 septem 0 *viculae, ${ }^{8}$ septem mulieres apud

1 J.T.S. April rgo6, p. 459 .

${ }^{2}$ Lambeth ${ }_{4} \mathrm{I}_{4}$ (originally $8_{5} \mathrm{I}$ in the Labrary of St Augustine's, Canterbury). This MS, used by Routh and others, had been lost sight of, and I should have been unable to collate it, but for a letter from Mr A. Souter in the Athenaeum, Aug. 20, 1904, p. 240, mentioning that he had found it, with the help of Dr M. R. James's Ancient Libraries of Canterbury and Dover. The fragment will be found in Routh's Reliquiae sacrae iii, reprinted in Migne P.L. vol. v. 
Esajam, 'septem ecclesiae apud Paulum, ${ }^{10}$ septem diacones, "septem angeli, ${ }^{12}$ septem tubae, ${ }^{13}$ septem signacula librn, ${ }^{14}$ septem septimanae quibus pentecosten concluditur, ${ }^{15}$ septem septımanae apud Danıhelum, item quadraginta tres septimanae apud Danihelum, ${ }^{16}$ apud Noe septem omnia munda in arca, ${ }^{17}$ septem vindictae de Cain, ${ }^{18}$ septem anni remittendi debiti, ${ }^{19}$ lucerna cum septem orificis (-ciis), ${ }^{20}$ septem columnae sapientiae in domo Salomonis.

' Nunc igitur de inenarrabili glona dei in providentia videas memorarı; tamen ut mens parva poterit conabor ostendere. Ut Adam illum per septımanam reformaverit, atque universae suae creaturae subveniret (subvenerit), nativitatem filii sui Iesu Christi domini nostri factum est. Quis itaque lege dei doctus, quis plenus Spiritu sancto, non respiciat corde ea die Gabrihel angelum Mariae virgini evangelizasse qua die draco Aevam seduxit; ea die Spiritum sanctum Mariam virginem inundasse qua lucem fecit; ea die in carne esse conversum qua terram et aquam fecit; ea die in lacte esse conversum qua stellas fecit; ea die in sanguine qua terra et aqua foetus suos ediderunt; ea die in carne esse conversum qua die hominem de humo instruxit; ea die natum esse Christum qua hominem finxit; eadem die esse passum quo Adam caecidit; ea die resurrexit a mortuis qua lucem fecit.

'Humanitatem quoque suam septimano (sepienaro) numero consummat, nativitatis, infantiae, pueritiae, adulescentiae, iuuentutis, perfectae aetatıs, occasum (-sus). Iudaeis quoque humanitatem suam etiam his modis ostendit. cum esurit, sitit, cibum potumque dedit,' cum ambulat eas esse scit (et sedet ?), cum super cervicalem dormivit. Cum autem freta aut procella (l) pedibus ingreditur, ventis imperat, aegros curat, et clodus (-dos $2 \mathrm{~m}$.) reformat, caecos [visu, mutos] eloquentia Instutuit ${ }^{2}$ videte dominum se esse nuntiari eiusdem (eisdent).'

Before this passage there is a comparison of the seven days with the seven heavens and the seven gifts of the Holy Ghost, partly to be quoted later. The long list of sevens is found twice in St Cyprian (Testimonia i 20, and ad Fortunatum $\mathrm{r}$ ). But St Victorinus is not quoting from him, as I hope the appended note will clearly shew ${ }^{3}$.

I Sumit is wanted. I suppose edit will not do with potum, even in Victorinus.

${ }^{2}$ We may perhaps read 'caecis visum, mutis loquelam restituit'. Routh suggested: "Forte excidit "surdos fecit audire et mortuos restituit," leaving the gift of speech to the blind as needing no emendation! But we want a seventh miracle. Perhaps 'freta pedibus ingreditur, ventis aut procellis imperat'. Or else 'caecis visum, surdis auditum, mutis loquelam'.

3 I give the two passages of St Cyprian. The text of that from the Testimonia is that of the MS L, from Hartel's apparatus: that of the Ad Fortunatum is Hartel's text, except that I read Pelrum for petram (a mere slip of S, corrected by the second hand) :-

St Cyprian Testim. i 20 'Item un Basi[li]on primo: "Sterilis septem peperit, et quae plurimos habebat filios, infirmata est." Filii autem ecclesiae septem sunt, unde et ${ }^{2}$ Paulus ecclesis septem scripsit, et Apocalypsis Ecclesias septem ponit, ut servetur septenarius numerus, ut ${ }^{a}$ dies septem quibus Deus mundum fecit, ${ }^{11}$ ut angeli septem, qui adsistunt et conversantur ante faciem Dei, sicut Raphael angelus in Tobia dicit, ${ }^{19}$ et lucerna septiformis in tabernaculum martyrii, et ${ }^{2}$ oculi Domini septem qui mundum speculantur, ${ }^{3}$ et lapis cum oculis septem, ut Zacharias dicit, et 4 spiritus septem, et ${ }^{\circ}$ candelabra in Apocalypsi septem, et ${ }^{20}$ columnae septem super quas aedificavit domum sapientia apud Salomonem.'

Idem ad Fortunat. I I 'Quid vero in Machabaeis septem fratres, et natalium 
Victorinus next applies the seven days to the Humanity of Christ, shewing that $\mathrm{He}$ sanctified the days of the week by certain events; then we hear of seven ages and of seven human and seven divine works.

The passage is corrupt and dislocated. Somewhat earlier in the

pariter et virtutum sorte consimıles, septenarım numerum sacramento perfectae consummationis implentes? Sic septem fratres martyrio cohaerentes, ut primi in dispositione divina ${ }^{a}$ septem dies annorum septem milia continentes ut 'septem spiritus et "1 angeli septem qui adsistunt et conversantur ante faciem Dei, et 19 lucerna septiformis in tabernaculo martyriı, et ${ }^{\circ}$ in Apocalypsi septem candelabra aurea, et ${ }^{20}$ aput Salomonem columnae septem super quas aedificat domum sapientia, ita et istic septem fratrum numerus, ecclesias septem numeri sui quantitate conplexus, ${ }^{\circ}$ secundum quod in primo Regnorum legimus sterilem septem peperisse. $\mathrm{Et}^{\mathrm{s}}$ apud Esaram septem mulieres unum hominem adprehendunt, cuius ınvocarı super se nomen exposcunt. Et ${ }^{\circ}$ Apostolus Paulus, qui huius numeri legitimi et certi meminit, ad septem ecclesias scribit. Et ${ }^{b}$ in Apocalypsi Dominus mandata sua divina et praecepta caelestia ad septem ecclesias et earum angelos dirigit. Qui nunc istic numerus in fratribus invenitur, ut consummatio legitima conpleatur. Cum septem liberis plane copulatur et mater, origo et radix, quae ecclesias septem postmodum peperit, ipsa prima et una super Petrum Domini voce fundata.'

If we number the members of Victorinus's enumeration, from I to 20 , they recur in Cyprian thus, Testim. 9, a, x1, 19, 2, 3, 4, 6, 20; ad Fortun. a, 4, 11, 19, 6, 20, $c, 8,9, b$. The addition in Cyprian which I have marked $b$, is not really an addition,-the seven Churches and seven angels of the Apocalypse,-for Victormus discusses them at length in his commentary on the Apocalypse, and here he may be supposed to refer to all the sevens in the first chapter of the Apocalypse under the heading septem candelabra. The addition marked $a$ is precisely what Victorinus is commenting upon, viz. the seven days of creation. The addition in ad Fortunatum, $c$, 'sterilis septem peperit' is the point on which the passage of the Testimonia comments. The whole list in ad Fortunatum is to illustrate the seven Maccabees. A very simple consideration will now demonstrate that Victorinus has not used Cyprian. The treatise ad Fortunatum is later than the Testimona; it gives most of the same sevens, adding the stertis septem peperit which is the text of the sermon in the former work. Both treatises cite the seven days which form the text of Victorinus's sermon, but are not in his list. But Victorinus has neither of Cyprian's texts, -neither the sterlis septem pepent nor the seven Maccabees. Yet if he had made up his hst out of St Cyprian's two lists, these two members of the enumerations were just those he could not have avoided giving. On the other hand Cyprian adds nothing to Victorinus except precisely the two points which give occasion to his two lists. It is clear, therefore, that Victorinus did not borrow from Cyprian, but that Cyprian has twice employed a source which Victorinus has followed more closely and completely. Whether the points given by Victorinus which are not in Cyprian were added by the former, or found in the source, we cannot, of course, know. All we know is that Cyprian borrowed from a source in which all the sevens were used to illustrate the seven days. (As Papias lived but a few miles from Laodicea and Colossae, he was in a Pauline circle. The idea that he knew nothing of St Paul is fortunately long since superannuated; and there is nothing impossible in his having put the epistles of St Paul to seven Churches as a parallel to those of St John as in the Muratorian fragment.) On the sources of the Testimonta see J. R. Harris in Expostor, Nov. 1906. 
fragment we find 'Die quinto terra et aqua foetus suos ediderunt', else one would have suggested in this passage aer or aera et aqua; for birds and fishes belong to the fifth day, and beasts to the sixth. Of the sixth day the earlier passage has, as ours has, 'Ac sic Deus hominem de humo instruxit.' A little later, the comparison of the seven days with the seven gifts supplies us with another list, the former of the following columns ; the second column gives the list in our passage :-

I. cum lucem fecit.

2. cum caelum.

3. cum terram et mare.

4. cum solem et lunam caeteraque clara.

5. cum terram ac mare excitat.

\section{6. cum hominem finxit.}

I. qua lucem fecit.

3. qua terram et aquam.

4. qua stellas.

5. qua terra et aqua foetus suos ediderunt.

6. qua $\left\{\begin{array}{l}\text { hominem de humoinstruxit. } \\ \text { hominem finxit. }\end{array}\right.$

Evidently it is the second day that is omitted. The Incarnation is on the first day, the Nativity, with the Passion, on the sixth. Between these there are wanted four stages of growth in the womb to correspond to the four intervening days; in fact, only three stages are mentioned, for in carne esse conversum comes twice over. The succession, milk, blood, flesh, was a commonplace. We find it in St Augustıne :-

\footnotetext{
'Sex, nouem, duodecim, decem et octo, haec in unum fiunt quadraginta quinque. Adde ergo ipsum unum, fiunt quadraginta sex : hoc sexies, fiunt ducenta septuaginta sex. Dictur autem concepto humana sic procedere et perfici, ut primis sex diebus quast lactis habeat simultudinem, sequentibus nouem diebus conuertatur in sanguinem, deinde duodecm diebus solidetur, reliquis decem et octo diebus formetur usque ad perfecta lineamenta onnsum membronum, et hinc iam reliquo tempore usque ad tempus partus magnitudine augeatur. Quadraginta ergo quinque diebus addito uno, quod significat summam : quia sex et nouem et duodecim et decem et octo in unum coactis, fiunt quadraginta quinque, addito ergo, ut dictum est, uno, fiunt quadraginta sex. Qui cum fuerint multıplicatı per ipsum senarium numerum, qui huius ordinationis caput tenet, fiunt ducenti septuaginta sex; id est, nouem menses et sex dies, qui computantur ab octauo calendas aprilis, quo die conceptus Dominus creditur, quia eodem die passus est, usque ad octauum calendas ianuarıas, quo die natus est. Non ergo absurde quadraginta sex annis dicitur fabricatum esse templum, quod corpus eius significabat, ut quot anni fuerunt in fabricatione templi, tot dies fuerınt in corporis Domınici perfectione.' (De Diuersis Quaestiontbus, ad Simplicianum 56 ' De annis quadraginta sex aedificati templi', begun A.D. 388.)
}

The same ingenious calculation is repeated by St Augustine in his De Trinitate (iv 5 n. 9). ${ }^{1}$ Only there he merely makes $46 \times 6=276$

1 The Ven. Bede, In S. Ioannis evang. Expos. ii 20, copies St Augustine $A d$ Simpl. almost word for word; he begins 'Tradunt enim naturalium scriptores rerum'. He adds another explanation of the forty-six years from Augustine Tract. 
days equal to the nine months from March 25 to December 25 (of these dates he says 'sicut a maioribus traditum suscipiens Ecclesiae custodit auctoritas '), and he says nothing of the milk, blood, and flesh, the $6,9,12$, and 18 days. In fact these only make 45 , not 46 , and addito uno, quod significat summam was an awkward expedient. From what medical authority St Augustine got these numbers of 6, 9, I2, 18, I do not know; but they were not known to Victorinus, for they cannot be made to give consecutive weekdays. Similarly Victorinus cannot have meant March 25 and December 25, which cannot fall on the same weekday. His only point of contact with Augustine is the series : milk, blood, flesh, growth. We get the following scheme:-
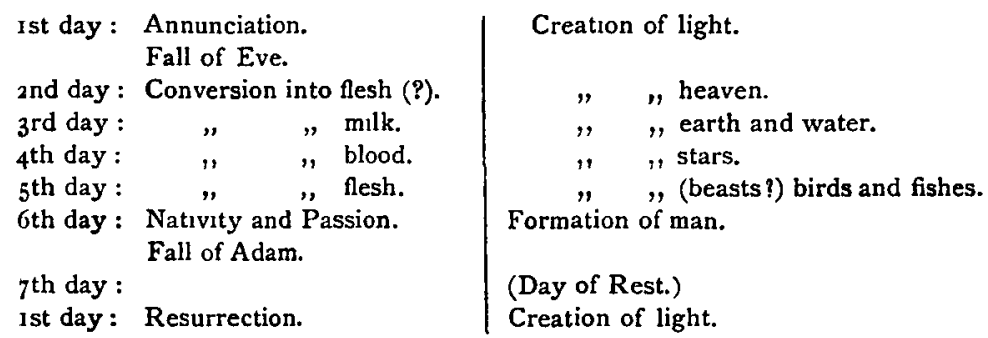

But whether this diagram is so far correct or not, at least it seems that even more is wanting. We should have expected to be told again that Christ was taken prisoner (!) on the fourth day, Wednesday, as Victorinus had said already : ' Homo Christus Iesus, auctor eorum quae supra memoravimus, tetrade ab impiis comprehensus est. Itaque ob captivitatem eius tetrade $(m)$... superpositionem facimus." " And if so, we might suppose that the Baptism was mentioned on the fifth day, e. g. : 'ea die baptizatum esse Christum qua terra et aqua foetus suos ediderunt.'

The repetition of the first day looks like an interpolation, and cannot be retained unless we change resurrexit into resurrexisse.

$X$ in Ioann. ii 19 no. 12 (where that Doctor is borrowing from Pseudo-Cyprian De duobus Montibus Sina et Sion 4 p. 108), to the effect that $46=$ 'A $\delta \alpha^{\prime} \mu=a^{\prime}+\delta^{\prime}+$ $a^{\prime}+\mu^{\prime}$, i. e. $1+4+1+40 !$ Bede repeats the former explanation in a Homily, Bk. i 22 ; and we find the same over again in the Chronicon Palatinum cap. 12-13 (Mai Spicilegium and P.L. 94, 1167). This chronicle is directed against the Easter calculations of the 'Scotti', i.e. St Columbanus, without doubt. The first eleven chapters are from John Malala, and so is the list of Emperors (col, 1172-4). As this list ends with the ninth year of Justin II, it is clear that the chronicle of Malala must have ended at that date. It is worth while noting this, in case it has not been pointed out before, for the date of Malala is usually spoken of as doubtful, and the end of his chronicle (abridged) is lost in the Bodleian MS, the only one.

1 Epiphanius (Haer. 52, 26, clearly not from Hippolytus, but from the authority

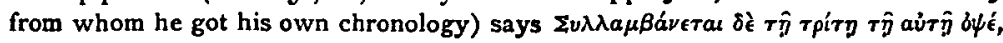
i. e. Tuesday! (Cp. Didaskalia 2I.) 
But the passage as a whole gives the three points which Hippolytus seems to have derived from Papias. It gives Sunday, the first day of Creation and the day of the Resurrection, as the day of the Annunciation. It applies to the growth of the humanity of Christ in His mother's womb the seven days of creation, thus suggesting, though not stating, that the period of gestation was seven months. Thirdly, as to the four days in the two lines of Dom Morin's fragment, it explicitly gives the right weekdays for the Annunciation, Nativity, and Passion, though it omits to mention the Baptism.

Now it cannot but seem remarkable, not to say startling, to find just these very points given in a single passage, when we remember that the weekday ascribed to the Nativity is unique, and that the seven months of gestation are only found (so far as I know) in Epiphanius. If we can find sufficient reason for believing that Victorinus is reproducing a passage of Papias, we shall have found an ample explanation of the mysterious appeals to the Apostles which we found apparently attributed to Hippolytus. ${ }^{1}$

\section{§2. Victorinus borrowed from Papias.}

It is certain that Victorinus in his Commentary on the Apocalypse borrowed largely from Papias. ${ }^{2}$ Indeed his millenarian conclusion to

1 It seems hardly necessary to point out that this passage of Victorinus and the other tiny fragment which cites Alexander are quite independent of one another, though the former seems to quote directly the source to which the latter goes back indirectly.

2 This is seen in the pre-Hieronymian form of the Commentary, as yet unpublished. - Haussleiter (Theol. Literaturblatt April 26, 1895, p. 199) pointed out that Victorinus quotes Papias about St Mark. Prof. Rendel Harris (Expositor 1895, 5th series, vol. i, 'A new Patristic fragment,' p. 453) has said: 'The proof of the borrowing must be left until Prof. Haussleiter's edition comes out; but in the meantime he has published sufficient text to enable us to recognize that the writer was following a biblical argument for Chiliasm which made the same quotations as Irenaeus, and was in harmony with the interpretations given by that Father. At the same time it is pretty certain that he is not retaling Irenaeus, of whom he shews himself, as far as we can judge at present, quite independent.' I have transcribed the Vatican MS Ottobon. lat. 3288 A from a photograph; it contains the Commentary on the Apocalypse in a form as yet unaltered by Jerome. An elaborate comparison with Irenaeus has convinced me that Prof. Harris is certainly right. That Irenaeus is using Papias in Bk. v ch. 25-36 is obvious, not only from the chiliastic matter, but from his actual citations of 'the presbyters' from time to time $\left(30,1 ; 33,3 ; 3^{6}, 1\right)$, while he appeals to Papias by name in 33,3 . Besides, Eusebius in 39 implies that Irenaeus followed Papias, while the fragment of Philip

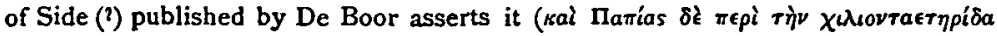
$\sigma \phi a ́ \lambda \lambda \epsilon r a$, , '́ seems to be quoting Maximus Confessor, or the source used by him (Schol. in Dionys. A reop. 'de eccl. hier.' 7). 
that work (omitted in St Jerome's revised edition of it) was clearly based upon Papias, just as was the similar disquisition in the fifth book - of St Irenaeus. Detailed resemblances are not wanting in other points. Victorinus-in the original form of his work-quoted Papias on Mark : - Marcus interpres Petri ea quae imminere ( $=$ in munere) docebat commemoratus conscripsit sed non ordine[m] et incipit prophetae per Esaiam praedicatio.' Again Victorinus makes the 24 elders mean the 24 books of the O.T.; and this is expressly attributed by Mommsen's catalogue ('Cheltenham list') to 'the Presbyters' (of Papias, no doubt). ${ }^{1}$ Again St Victorinus's comparison of the four beasts with the four Gospels, before St Jerome altered it, was parallel to that of St Irenaeus, and yet a detailed comparison prevents us from supposing it to be borrowed from St Irenaeus; at least so it has seemed to me after very careful study. There are other reasons for attributing this to Papias. It is not necessary to shew at length how the twenty-four books of the

1 Mommsen's list has: "Sed ut in apocalypsi Iohannis dictum est: "vidi xxiiii seniores mittentes coronas suas ante thronum," maiores nostri. probant hos libros esse canonicos et hoc dixisse seniores.' I cannot agree with the ingenıous translation of the last words, proposed independently by Zahn and Turner: 'that the 24 elders signify this.' I doubt whether dixisse (why not dicere?) could mean this, and I feel no difficulty in taking seniores in two different senses, in the first place as 'the Elders of the Apocalypse', in the second place as 'the Presbyters of Papias'. I translate : 'But as it was said in the Apocalypse of John "I saw 24 elders casting their crowns before the throne", our predecessors prove these books to be canonical, and that the Presbyters said this.' We have here two stages of tradition: maiores nostri, and bebind them seniores, which was well understood to mean men who had known the Apostles. Dom Morin has called attention to Victorinus's remark ( $J$.T.S. Igo6, April, p. $\left.45^{6}\right)$, but not to all the three passages. They read thus in the pre-Hieronymian version (I cite from a photograph of MS Vat. Ottobon. lat. $3^{288} \mathrm{~A}$ ) : ' xxiii seniores habentes tribunalia xxiiii libri prophetarum et legis referentes testimonia udicio. sunt autem xxilii patres xii apostoli duodecim patriarchae' ( fol. $6 v$. and $7 r$.), and 'alae testimonia*** veteris testamenti sunt librorum ideoque xxirii sunt tot numero quidet (i. e. quot et) seniores super tribunalia' ( $f o l .7 v$.), and 'sunt autem libri veterıs testamenti qui exclplunt xxiiii quos in epithomis Theodori invenimus'. For excipiunt (the sign for ur has been accidentally omitted) the Babl. Cassin. (v I p. 7) gives excipruntur, no doubt the right reading, whereas the text in Bubl. Max. PP. has accipiuntur, and that of Migne (Gallandi) has recipiuntur. All these printed texts have inventes, which probably represents St Jerome's text. Is it possible that Jerome, not knowing any more than we do what were the epitomae Theodori, changed invenimus to invenies? I daresay Zahn is right in thinking the excerpta ex Theodoto to be meant (Forschungen iii p. 129), and Sanday (Stud. Babl. iii p. 238) has agreed with him. Now Dom Morin has arrived independently at the same view. I do not accept Zahn's argument that there must have been a list in a lost portion of the excerpta ex Theodoto, but it is possible. And I am ready to accept as quite possibly true Dom Morin's suggestion that the Muratorian fragment is a portion of that work, rather than of the Hypotyposes, as 1 formerly tried to shew, Rev. Bén. July, I904. 
O. T., the four Gospels and the seven Epistles of Paul are mystical numbers likely to be borrowed from a common source. We saw the seven Epistles taken by Cyprian and by the De fabrica mundi from a common source, and in the Commentary on the Apocalypse Victorinus enlarges upon the same point. (Of the Muratorian fragment I wish to say nothing here.) The four Gospels and the four beasts occur together in the earlier part of De fabrica mundi.

So far I have been summarizing at length an argument which implies that Victorinus and Irenaeus have in many places copied Papias independently. This will be admitted as fairly certain in the case of the chiliastic passages; as to the other points a longer disquisition would be needed. It must be added that it is probable that Victorinus, if he used Papias, would sometimes copy him word for word ; at least we know that he treated Origen in this way :-

'Taceo de Victorino Petabionensi et ceteris, qui Origenem in explanatione dumtaxat Scripturarum secuti sunt ex expresserunt' (Jerome Ep. $7 \mathrm{I}, 2$ ).

' Nec disertiores sumus Hilario, nec fideliores Vactorino, qui eius (sc. Origenis) tractatus non ut interpretes, sed ut auctores proprii operis transtulerunt' (zd. Ep. 84, 7).

Now there is much in the De fabrica mundi which it is impossible to suppose borrowed from Papias, but there is much which seems most likely to come from him. Not only the long list of sevens, which St Cyprian also gave, but the preceding list of fours may well be his. The proof rests upon the fact that Papias was the first of the long line of Greek fathers who occupied themselves with the seven days of Creation, as we learn from Anastasius of Mount Sinai :-

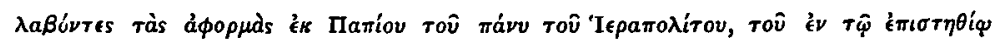

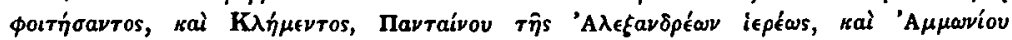

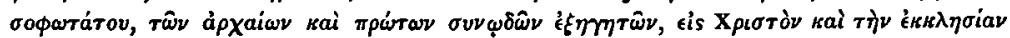

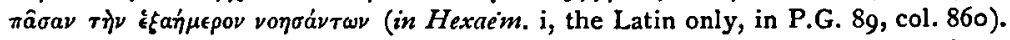

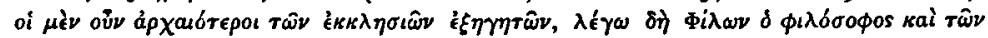

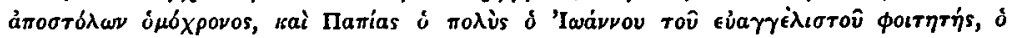

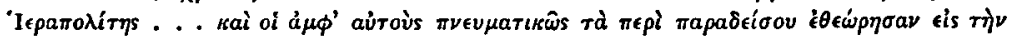

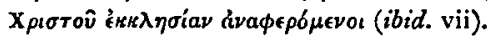

It does not seem clear (or even very likely) that Anastasius had read Papias, though his contemporary and fellow fighter against Monothelitism, St Maximus Confessor, had the book. It may be that he took this information from Clement (whose dissertation on the subject will have been in the first book of his Hypotyposes ${ }^{1}$ ), or from some other early writer. The application of the seven days to the Church will doubtless have made the seventh day the millennium, proving the

1 In the Hypotyposes Papias was used; at least the story of the writing of St Mark's Gospel is mediately if not immediately from him. Pantaenus was cited by name (Euseb. H.E. v II).

VOL. IX. 
identity by the familiar saying that 'one day with the Lord is as a thousand years ', ' which we find thus cited by Justin and Irenaeus (who both evidently founded their chiliastic theories on Papias) and by Hippolytus.

We must now look at the whole passage from De fabrica mundi, quoted above, and detail the reasons for believing it to be founded on Papias.

I. It has been shewn to give exactly the information which Annianus, Epiphanius, and Alexander led us to believe was ascribed by Hippolytu's to 'one who knew the Apostles', apparently Papias.

2. The De fabrica mundi does interpret the seven days as referring to the Church, precisely in the way we should expect from Papias, according to the account of Anastasius, the seventh day being the millennium. The passage is corrupt, as usual : we are told of Old - Testament worthies who broke the Sabbath :-

' Ut verum illum et iustum sabbatum septımo milliario annorum observaretur. Quamobrem septem diebus istis Domınus singula millı annorum adsignavit, sic enim cautum est : "in oculis tuis, Domine, mille anni ut dies una" (Ps. 89). Ergo in oculis Dei singula millia annorum constituta sunt, septem enim rhabet oculos Dominus ${ }^{12}$ (Zech. iv 10). Quapropter, ut memoravi, verum illud sabbatum ${ }^{5}$ erit septimo milliario annorum in quo Christus $^{73}$ cum electis suis regnaturus est' (Apoc. $\mathrm{xx} 4$ ).

Here we find the obvious citation of Psalm 89, and of the locus classicus from the Apocalypse, and all that a priori Papias should have said. The parallel with Irenaeus is very close."

3. But Anastasius says 'of Christ and His Church'. How can the seven days be interpreted of Christ? The fragment will tell us. The

1 From Ps. lxxxix 4, not from 2 Peter iii 8.

2 The MS has 'habeo oculos Domini'.

'So Routh for the manuscript reading 'et septem milia anni in quo xps'. Migne (following other edd. ") omits in, which is in the MS.

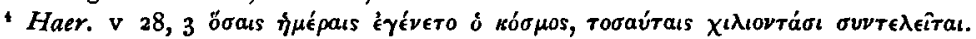

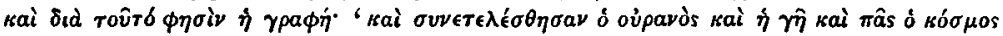

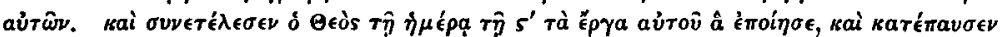

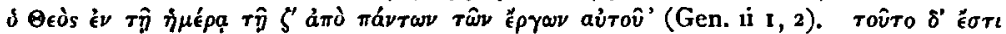

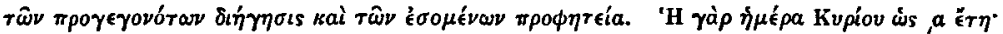

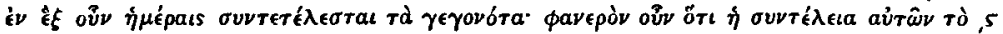
Éros $\epsilon_{\sigma \tau i \nu}$. Cp. Justin Dial. 81 p. 295, where the Psalm is quoted and then the text of the Apoc. is referred to. In a fragment of Methodius (ap. Pitra Anal. ini 610) which Zahn (G.K. i $3^{1} 3$ note) thinks genuine, the citation is from 2 Peter, and the reference to Apoc. follows as usual. The 'thousand years as one day' is also found in Barnabas $1_{5}$, in Iren. $\mathbf{2}_{23}, 2$, in Hippolytus on Daniel, in the fragments of Hippolytus against Caius, \&c. What Victorinus has to say on Apoc. xx 4 will be found given by Haussleiter, in the Theolog. Literaturblatt, 26 Apri 1895 , col. 196, from the Ottob. MS. 
same passage goes on to say that 'the seven heavens agree with the seven days', and so do the seven spirits with the seven heavens.

"rAuctor autem totius creaturae Iesus, ${ }^{11}$ verbo cognomen est ei . . Hoc igitur verbum, cum lucem fecit, sapientia vocatur ; cum caelum, intellectus; cum terram et mare, consilium ; cum solem et lunam caeteraque clara, virtus; [cum] terram ${ }^{2}$ et mare excitat, scientia ; cum hominem finxit, pietas; cum hominem benedicit et sanctificat, timor Dei nomen habet.'

If this is not thought to be a direct application to Christ, we shall find a better one in the passage already cited, emendated, and discussed ; we saw the growth of His human Body in the womb applied to the seven days of the week; we saw that His 'humanity was consummated' by seven stages of life, from birth through childhood to manhood and death; that it operated in seven kinds of divine works and seven kinds of human works. ${ }^{3}$ And all this was in illustration of the hexaëmeron of creation, thus exactly corresponding to the statement of the monk of Sinai.

4. The reference to Eve will need a longer handling: 'ea die Gabrihel angelum Mariae virgini evangelizasse qua die draco Aevam seduxit.' The doctrine that Mary corresponds to Eve is found in Justin Dial. ror p. 327 c (he knew and used Papias's work, I think), in Irenaeus iii 22 and $\mathrm{v}$ I9 (he made great use of it), in Tertullian De carne Christi $\mathrm{I} 7$ (where Irenaeus is certainly the authority), and in Epiphanius and the later Fathers. Now Irenaeus may have elaborated what he found in Justin, or we may simply say that it was already a preacher's commonplace, or we may think that both used a common source. But in any case what we find elaborated by Justin may very well have been hinted at by Papias. One point, however, is of itself interesting; it is the use both by Justin and by Victorinus of the

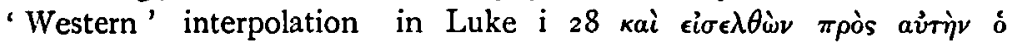

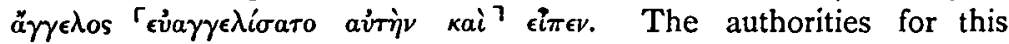
variant are $\Lambda 229262 * 2^{\text {pe }} 6^{\text {pe }}$ syrp $^{p}$ Justin ; b Ado, Victorinus (evangelizavit); a e ff ${ }^{2} 1$ (benedixit) 4. Remark how varied is the evidence: Greek-Western, African and European Latin, Syriac. It is impossible. to doubt that $\mathrm{D}$ has here, as often, lost the original Western reading of its parent.

1 The MS has 'auctontatem totius crealurae ustus'; the correction is Walker's.

$2 c \bar{u}$ is added by the second hand; the first hand wrote terrae, the second hand changed $e$ to $m$.

3 This would have made a good excerpt for the Fathers of the seventh century to quote against the Monothelites. St Maximus seems to have known Papias's book (though perhaps Anastasius of Sinai did not), and one is surprised he did not notice this passage.

I do not know that the readings of Justin and Victorinus have been chronicled until now, at all events the latter. That of Ado (viii id. Octobr.) was given by my friend and confrère Dom Quentin in his most interesting paper on Codex Bezae in Revue Bénéd. Jan. 1906. 
But the reading of Victorinus is particularly noticeable, because there is no reason, I think, to connect his readings in general with those of the Codex Veronensis, which alone gives evangelizavit. $\mathrm{He}$ perhaps often translated his quotations from a Greek Bible, but in the present passage he is more probably literally rendering his source. His source for the whole passage was not Justin, but his likeness to the parallel passage of Justin is remarkable:-

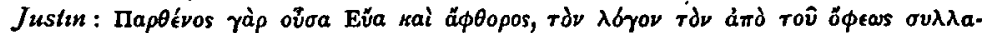

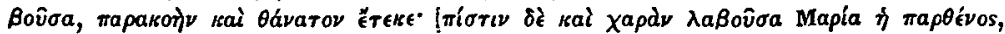

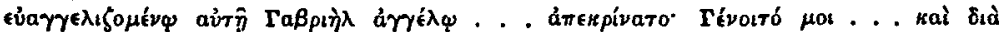

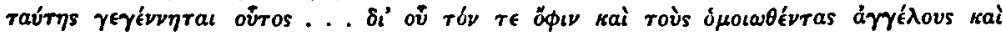

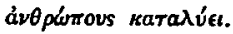

Victorinus: ea die Gabrzhel angelum Mariae virgini evangelszasse qua die draco Aevam seduxit.

Victorinus has not emphasized like Justin (and Irenaeus, \&c.) the virginity of Eve when she fell, but he mentions that of Mary. The parallel is between the speech of the angel and that of the serpent. And the rare evangelizavit gives a further resemblance.

- No doubt the connexion would not be obvious, were it not that we had already brought home the Victorinus passage to Papias with great probability. It seems that Justin may have been developing the same passage of Papias which Victorinus has used. ${ }^{1}$

5. Let us turn to the condemnation of Papias by Eusebius : $\mathbf{\Phi} \phi o ́ \delta \rho a$

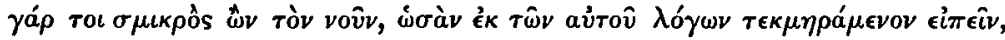

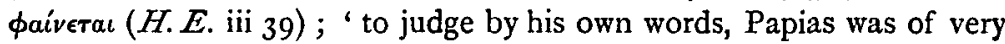
small understanding.' One naturally takes this to mean 'to judge by the silly chiliastic interpretations he puts forward'; but it might also mean : 'to judge by his own words about himself,' or more literally: ' if I may so speak, taking the expression from his own words.'

- The sentence of Victorinus is so short that he could not parallel the whole of Justin's passage; one would suppose the simpler and shorter to be nearer the original thought. Justin's idea of Eve listening to the serpent, Mary to the Angel, is implied by Victorinus. Irenaeus has greatly developed the thought, especially in the notion of the disobedience of Eve retracted by the obedience of Mary, after the model of Romans $v$ I9. Attention must be called to the draco for serpens in

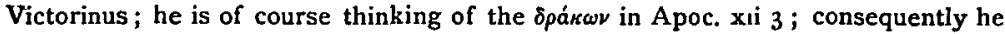
probably thinks of the woman in that chapter as Mary. But there is no direct trace of this thought in his Commentary on the Apocalypse, where he says of the woman 'ecclesia est antiqua patrum et' prophetarum et sanctorum apostolorum', etc. The dragon is the devil, 'diabolus est, angelus refuga,' etc. The child is 'He who was born without seed'; the Mother is therefore the Vurgin Mother, representing the Church. I suppose this is the usual interpretation both among the Fathers and the moderns. But it is curious that Victorinus in the chiliastic ending of his Commentary conversely calls the dragon of the Apocalypse 'anguis'. 
Turn back to De fabrica mundi, at the beginning of the quotation given above: 'Nunc igitur de inenarrabili gloria Dei $^{1}$ in providentia .videas memorari ; tamen ut mens parva poterit, conabor ostendere." Now mens parva is the most exact translation possible of orıкpòs voûs. Is it possible that Eusebius, in his vexation at the obstinate millenarianism of a sub-apostolic writer, seizes upon an expression used by Papias of himself in quite commonplace humility, and brutally declares that it is just the epithet which suits him? 'For indeed he had a very "small mind", if I may use his own expression.' I think it at least worth while to make the suggestion, and the reader can laugh if he likes. ; 6. Then we have had the proof that Victorinus and Cyprian were both using an earlier writer on the number seven, who probably was commenting on the seven days; and considerations as to the numbers 4 and 24 were attributed to Papias.

7. Lastly, the words of De fabrica mundi about the seven ages through which Christ passed seem to be the very words upon which St Irenaeus founded his notion that our Lord lived to the age of fifty or thereabouts. This will furnish the matter of our last section.

\section{§ 3. St Irenaeus on the age of Christ.}

The well-known passage of St Irenaeus runs as follows :-

ii 22, 4-5 'Triginta quidem annorum existens cum veniret ad baptismum, deinde magistri aetatem perfectam habens, venit Hierusalem, ita ut ab omnibus iuste audiret $^{2}$ magister; non enim aliud videbatur et aliud erat, sicut inquiunt qui putativum introducunt; sed quod erat, hoc et videbatur. Magister ergo existens, magistri quoque habebat aetatem, non reprobans nec supergrediens hominem, neque solvens [suam] legem in se humani generis, sed omnem aetatem sanctificans per illam quae ad ipsum erat similitudınem. Omnes enim venit per semetipsum salvare : omnes, inquam, qui per eum renascuntur in Deum, infantes et parvulos et pueros et iuvenes et seniores. Ideo per omnem venit aetatem, et infantibus infans factus, sanctificans infantes ; in parvulis parvulus, sanctificans hanc ipsam habentes aetatem, simul et exemplum illis pietatis effectus et iustitiae et subiectionis; in iuvenibus iuvenis, exemplum iuvenibus fiens et sanctificans Domino, sic et senior in senioribus, ut sit perfectus magister in omnibus, non solum secundum expositionem veritatis, sed et secundum aetatem, sanctificans simul et seniores, exemplum ipsis quoque fiens; deinde et usque ad mortem pervenit, ut sit "primogenitus ex mortuis", "ipse primatum tenens in omnibus", "princeps vitae", prior omnium, et praecedens omnes.'

I have italicized certain words for convenience in referring back to the passage.

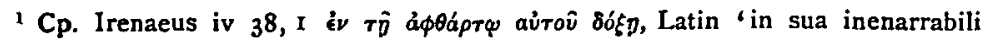
gloria'.

${ }^{2}$ Harvey makes the astounding comment: 'The Claromontane reading audiret followed by Massuet makes no sense!' Of course it -means. 'was called', like dxov́d, of which it is the rendering, and like 'hear' in Spenser, Milton, etc. 
Though many of the early Fathers, or most of them, held that our Lord's public ministry lasted only one year, St Irenaeus thinks this opinion heretical. At the beginning of this chapter he had shewn it to be inconsistent with St John's Gospel. In the passage I have quoted he states that though Christ was 30 at His Baptism, He did not come to Jerusalem to teach until He had attained the magistri perfecta aetas, for it would have been against His own law to preach when younger. The age of forty is meant.

St Irenaeus goes on, $\mathrm{He}$ wished to save and sanctify all ages, infantes, parvulos, pueros, iuvenes, seniores. Here are five ages enumerated, apparently as exhaustive. He takes them up again, infantes, parvuli, iuvenes, seniores. This time pueri are omitted, and he makes it clear that seniores are in 'the perfect age of teacher', 'sic et senior in senioribus, ut sit perfectus magister in omnibus . . ., sed et secundum aetatem.' One point is added, death, which Christ also sanctified. The scheme will be one of seven stages, if we supply 'birth', as the mention of death obliges us to do.
$1^{0}$
$2^{\circ}$
I. (nativitas).
2. infantes.
infantes.
3. parvuli.
parvuli.
4. pueri.
5. iuvenes.
iuvenes.
6. seniores.
7 .
seniores or perfecti.
mors.

In English it would seem extremely odd to say that man's life is divided into (I) babyhood, (2) childhood, (3) boyhood, (4) youth, (5) grown-up age. We should expect this last to be developed into 'prime of life', 'middle age', 'old age', 'senility or decrepitude', if the first four divisions are to be balanced. Of course 'youth' lasted longer in the view of the ancients. A Roman was technically a iuvenis until 46 , when he became a senex. Cicero makes old age follow incontinently upon youth: "Citius adolescentiae senectus quam pueritiae adolescentia obrepit' ( $D e$ Senect. ii). St Benedict makes fifteen years the limit of infancy: 'Infantum vero usque quindecim annorum aetates ...'(Reg. 70). Sallust calls Caesar adulescens at 33 or 35 (Cat. 49). Varro counts pueri up to 15 , adulescentes up to 3 . Cicero calls Cassius an adulescens at 34 ; he applies the same word to Brutus and Cassius at $4 \mathrm{I}$, and to himself when consul at 44 (Orat. ii 2 ; Phil. ii 44 and 46 ). We cannot give Greek examples, as we cannot tell what Greek words St Irenaeus used. ${ }^{1}$

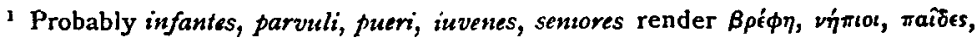

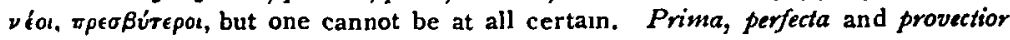


But such considerations do not destroy the difficulty. The key seems to lie in the fact that Irenaeus makes senior aetas the perfecta aetas. The four kinds of youth do not represent four-fifths of human life, they

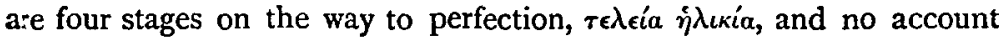
is taken of the descent, the decline which begins after this. It would be an imperfection, not assumed by Christ. Irenaeus continues :-

'Illi autem, ut figmentum suum de eo quod est scriptum "vocare annum Domini acceptum" affirment, dicunt uno anno eum praedicasse et duodecimo mense passum, contra semetipsos obliti sunt, solventes eius omne negotium, et magis necessariam et magis honorabilem aetatem eius auferentes, illam inquam provectiorem, in qua et docens traeerat universis. Quomodo enim habuit discipulos si non docebat? Quomodo autem docebat magistri aetatem non habens? Ad baptismum enim venit nondum qui triginta annos suppleverat, sed qui inciperet esse tanquam triginta annorum : iita enim qui eius annos significavit Lucas posuit: "Iesus autem erat quasi incipiens triginta annorum" cum veniret ad baptismum), et a baptismate uno tantum anno praedicavit ; complens trcesimum annum passus est, adhuc iuvenis exsistens, et qui necdum provectiorem haberet aetatem. Quia autem triginta annorum aetas prima indolis est iuvenis, et extenditur usque ad quadragesimum annum, omnis quiltbet confitebitur; a quadragesimo autem et quinquagesimo anno declinat iam in aetatem seniorem, quam habens Dominus noster docebat, sicut Evangelium et omnes seniores testantur qui in Asia,' etc.

The heretics, he says, make our Lord preach just 12 months from His entrance upon His $3^{\circ}$ th year; so that He lived only $3^{\circ}$ years complete, and was but a youth. ${ }^{1}$ For 'every one will agree' that the first maturity of youth (aetas prima indolis iuvenis, $\dot{\eta} \lambda \iota \kappa i a ~ \dot{\eta} \pi \rho \omega \dot{\tau} \eta$ $\ddot{\eta} \theta$ ovs véov, I suppose) is 3 , and it (i. e. aetas indolis iuvenis) extends to 40. Then begins a decline into aetas senior, $\eta^{\prime} \lambda \iota \kappa i ́ a ~ \pi \rho \epsilon \sigma \beta v \tau \epsilon$ ' $a$, 'older maturity or manhood,' until $50^{2}$ I presume indoles iuvenis will be

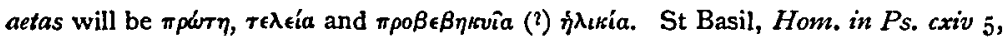

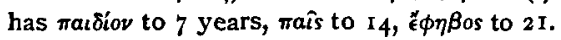

1 It would seem to be assumed that the Birthday and Baptism day were the same, as indeed the Easterns kept them on January 6, until at the end of the fourth century they borrowed the Western Christmas. Did Irenaeus, or did Ptolemaeus, already set down January 6 for both events? Certain Basilidians placed the Baptism on that day (Clement Strom. 121 pp. 407 408 Potter).

- Harnack has taken aetas senior to mean literally old age, Greisenalter, and not merely (as it does) 'older age', and he supposes that Irenaeus is trying to minimize this testimony (Chronol. i 335 note): 'The Presbyters of Asia Minor had witnessed that Jesus had arrived at old age, as a tradition received from John : Irenaeus believes, on the ground of the Gospel of John, that He arrived at an age of $4^{\circ-50}$ years, and seeks to harmonize the two traditions.' The careful exposition I have given is enough to shew that this incredible view is not correct. Zahn was right in his reply (Forschungen vi $6_{3}$ note). It is clear that Irenaeus is not minimizing the witness of the Presbyters, but strains it to the uttermost. 'As he has forced the testimony of the fourth Gospel to say more than it really does say, so also he may have strained the testimony of "all the elders" in the same direction' (Lightfoot Supermat. Relig. p. 247). 


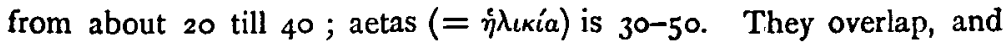

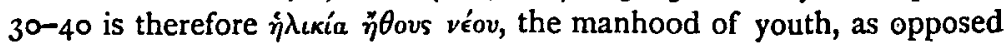
to the older manhood 40-50. The 'perfect age', or 'perfect age of a teacher', is 40 , while the 'first aetas indolis iuvenis' is 30 . Similarly in

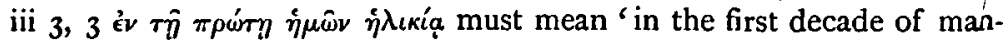
hood' or 'in early manhood', that is about $30-40$, or $30-35$, and cannot mean less than $3 \circ$, at which point St Irenaeus has set the beginning of $\dot{\eta}^{\prime} \lambda_{\iota \kappa}{ }^{\prime} a$ in its youthful period.' The whole system is as follows :-
I. [Nativitas]
2. infantes
$0-10$.
3. parvuli
$10-20$.
5. pueri $\mid \begin{gathered}\text { 5े } \\ \text { 5. iuvenes } \\ \text { पे } \\ \substack{\text { है } \\ \text { की }}\end{gathered}$
$20-30$.
30-40 (30 Manhood begins).
6. perfecti or seniores)
7. mors

But there is a confusion of thought in that Irenaeus makes it an imperfection not to have arrived at near 50, although the 'perfect age of a teacher', the 'more necessary and honourable age' of 40 begins a decline towards 50 , so that $40-50$ is a less perfect period. I can only suggest that he has misunderstood a system which made the sixth stage not a period, but a perfect age attained.

We now come to the authorities for this view of Christ's age, Scripture and Tradition. Tradition, is taken first :-

sicut evangelium

et omnes seniores testantur, qui in Asia apud

Iohannem discipulum Domini

convenerunt id ipsum

tradidisse eis Iohannem.

Permansit autem cum eis

usque ad Traiani tempora.

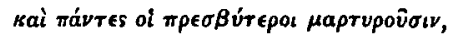
ol karà Tr̀v 'A áà

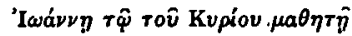

$\sigma \nu \mu \beta \epsilon \beta \lambda \eta \kappa \delta$ TєS

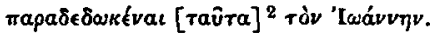

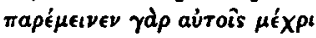

$\tau \hat{\omega} \nu$ T paıavồ Xpóvav.

'Quidam autem eorum non solum Iohannem sed et alios Apostolos viderunt, et haec eadem ab ipsis audierunt, et testantur de huiusmodi relatione. Quibus magis oportet credi 2 Utrumne his talibus, an Ptolemaeo, qui Apostolos numquam vidit, vestigium autem Apostolı ne in somniis quidem assecutus est ?'

Beyond all question Irenaeus is quoting from Papias; we have only'

1 See additional note at the end of this article.

2 ravita is not found in the citation by Eusebius (though Rufinus has haec), nor in Syncellus, but (teste Grabe) in Nicephorus. Zahn suggests that id ipsum rather renders raủrá or raủzó (Forsch, vi 6r note 3). 
to compare $\mathrm{v} 33,3$, where Irenaeus thus introduces the saying of the Lord about the vine with ten thousand shoots :-

'quemadmodum Presbyteri meminerunt, qui lohannem discipulum Domıni viderunt, audisse se ab eo...'

And after the citation he continues :-

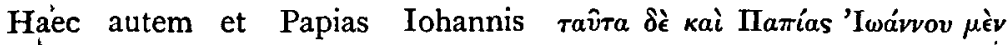

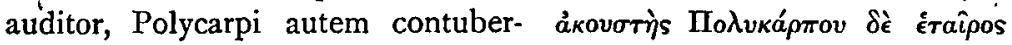

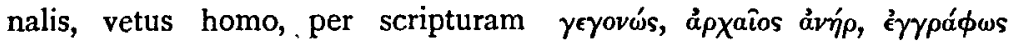

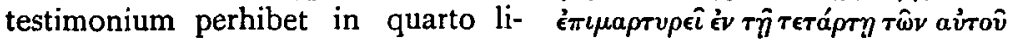

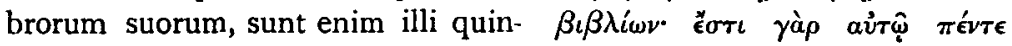
que libri conscripti.

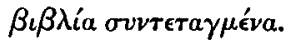

In the former sentence we have 'the Presbyters who saw John', just

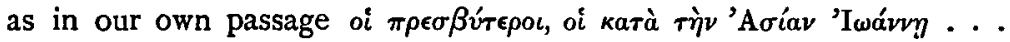
$\sigma v \mu \beta \epsilon \beta \lambda \eta$ кótєs. But the second sentence explains that this witness is written in the book of Papias. Zahn (Forschungen vi p. 89) has insisted that the kai means that Papias 'also' witnessed, i. e. that Irenaeus confirms the oral testimony of the Presbyters by the additional written witness of Papias. This seems to me quite impossible. Irenaeus means 'not only did they witness the fact, but also Papias has consigned their testimony to writing'. We know that this was precisely what Papias claimed to have done. But Papias was one of them, a 'hearer of John'. Now St Irenaeus is trying to make the most of his evidence. We need not suppose that here, or in $\mathbf{v} 30,1 ; 33,3$; 36, I, where 'the Presbyters' are cited, Papias had made any special quotation from 'the Presbyters'. But his Preface (Euseb. H. E. iii 37) claimed their authority in a general way for his doctrine, and he himself was one of them to St Irenaeus. Consequently St Irenaeus is ready to quote any remark of Papias to which he happens to take a fancy, as a tradition witnessed by 'all the Presbyters who consorted with John in Asia':

I suppose that for the age of our Lord he depends on a passage of Papias, ${ }^{1}$ which he presumes to rest not merely on the authority

1 Another point, in itself of great importance, suggests that a written authority

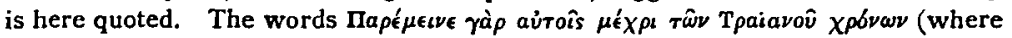
aùroîs means ' the Presbyters who knew John') occur again in iii 3,4 'A $\lambda \lambda a \grave{a}$ kaì $\dot{\eta}$

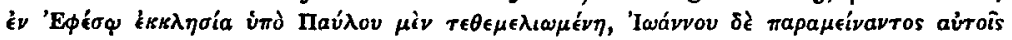

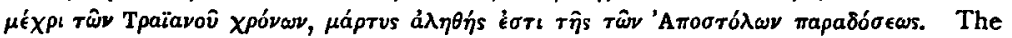
repetition of this phrase word for word suggests, or rather implies, that it is a verbal citation from a written source. The way in which it is inserted as an ablative absolute in the second passage is a confirmation of this, when considered in connexion with the awkwardness of aurois, which now refers vaguely to the

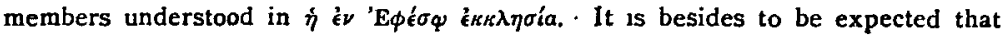
Papias will have somewhere mentioned to what late date John conversed with the 
of that disciple of John, but on that of all the disciples of John; for indeed, if one disciple of John testified that our Lord lived to the age of fifty, or nearly, all of them must have known this, and the testimony of Papias could not be isolated. ${ }^{1}$

And he was no doubt strengthened in his view by the fact that it was St John who in his Gospel shewed that Christ went up for more than one passover to Jerusalem (as Irenaeus had just proved), and again St John who testified that He had taught at Jerusalem publicly, i.e. as a 'perfect master'. St Irenaeus now clinches the argument by shewing that St John represents the Jews as recognizing that Christ's age was between forty and fifty. I give this remaining portion of our passage in a note. ${ }^{2}$

The argument is very forcibly put. We can well conceive that to

Presbyters. (Perhaps Papias had $\dot{\eta} \mu \hat{\nu}$ for aùrois.) I take it that the phrase is certainly borrowed from the book of Papias.

1 A perfectly clear reference to the Prologue of Papias is contained in the words: 'Quidam autem eorum non solum Iohannem sed et ahos Apostolos viderunt,' for they are based on Papias's declaration that he used to ask the Presbyters what this and that Apostle used to say. (Of course Irenaeus never thought of identifying 'Presbyters' and 'Apostles' in that sentence, as several moderns have done, e.g. Zahn, Bardenhewer, Michiels. But that point I cannot deal with here.) These references to the Prologue seem to me to imply that Irenaeus found in the passage of Papias which he employed no definite appeal to the Presbyters, so that the bishop of Lyons was driven to fall back upon the general appeal in the Prologue to Apostolic tradition through the Presbyters.

2 'Sed et ipsi qui tunc disputabant cum Domino Iesu Christo Iudaei apertissıme hoc ipsum significaverunt. Quando enım eis dixit Dominus: "Abraham pater vester exultavit ut videret diem meum, et vidit, et gavisus est," responderunt ei : "Quinquaginta annos nondum habes, et Abraham vidisti?" Hoc autem consequenter dicitur ei quı iam XL annos excessit, quinquagesimum autem annum nondum attıgit, non tamen multum a quinquagesimo anno absistit. $\mathrm{Ei}$ autem qui sit xxx annorum diceretur utique: "Quadraginta annorum nondum es." Qui enim volebant eum mendacem ostendere, non utique in multum extenderent annos ultra aetatem quam eum (eam, Harvey) habere conspiciebant : sed proxima aetatis dicebant, sive vere scientes ex conscriptione census, sive conicientes secundum aetatem quam videbant habere eum super quadraginta; sed ut non quae esset triginta annorum. Irrationabile est enim omnino viginti annos mentiri eos, volentes eum iuniorem ostendere temporibus Abrahae. Quod autem videbant, hoc et loquebantur; qui autem videbatur non erat putativus sed veritas. Non ergo multum aberat a quinquaginta annis; et ideo dicebant ei : "Quinquaginta annorum nondum es, et Abraham vidisti ?" Non ergo anno uno praedicavit, nec duodecimo mense anni passus est. Tempus enim a trigesimo anno usque ad quinquagesimum numquam erit unus annus, nisi si apud Aeones eorum tam magni anni sunt deputati his qui apud Bythum in Pleromate ex ordine resident, de quibus et Homerus poeta

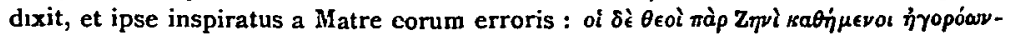

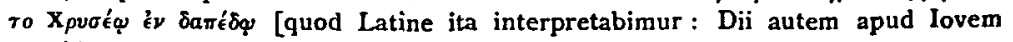
considentes tractabant aureo loco].' 
Irenaeus it seemed simply invincible, and that it strengthened him in what was apparently a misunderstanding of the words of Papias.

\section{\$ 4. Papias on the Age of Christ.}

What did Papias really say? I have already indicated that the answer seems to lie in the short passage of Victorinus De Fabrica mundi of which I have said so much.

'Humanitatem quoque suam septenario numero consummat, nativitatis, infantiae, pueritiae, adulescentiae, iuventutis, perfectae aetatis, occasus.'

On the last word Routh remarks: 'De morte vox interdum adhibetur.'

The parallel with the system of St Irenaeus is exact, and it confirms our suspicion that in the sixth place, of the alternatives senior aetas and perfecta aetas, ${ }^{1}$ the latter was in Irenaeus's source and not the former :-

\begin{tabular}{|c|c|c|c|}
\hline Irenaeus & Greek (?) & Victorinus & Age \\
\hline [nativitas] & & nativitas & \\
\hline infantes & $\beta \rho \varepsilon ́ \phi \eta$ & infantia & {$[0-10]$} \\
\hline 3 parvuli & $v \dot{\pi} \pi \iota \mathrm{c}$ & pueritia & {$[10-20]$} \\
\hline pueri & $\pi a \hat{\imath} \delta \epsilon \mathrm{S}$ & adulescentia & {$[20-30]$} \\
\hline 5 iuvenes & $\boldsymbol{\nu}^{\prime} o_{\ell}$ & iuventus & $30-40$ \\
\hline perfecta aetas & $\dot{\eta}^{\prime} \lambda_{\iota \kappa i ́ a} \quad \tau \in \lambda \in \epsilon^{\prime} \alpha$ & perfecta aetas & c. 35 ? \\
\hline mors & & occasus & \\
\hline
\end{tabular}

a. It need hardly be pointed out that Victorinus is not using Irenaeus. $\mathrm{He}$ is engaged in a discourse on the mystical number seven, whereas there is nothing in the passage of Irenaeus which suggests seven. We only made up seven stages by combining two lists of five, adding the necessary nativitas.

b. There is a difference of translation in 3 and 4 , parzuli and pueri being represented by pueritia and adulescentia. But Victorinus used the abstract nouns, and there is none corresponding to parouli; he was

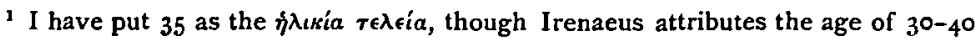
to the preceding stage, so that the number reáched should be $4^{\circ}$; for if ìnckia nैoovs véov, early manhood, is from $30-40$, and 30 is the first year of it, 35 may be taken roughly as its perfection. Again, the dictum of Psalm $89\left(9^{\circ}\right)$ was so well known that we expect the perfection of life to be half of the 70 years of man's age. But against this it may be urged that the highest point of perfection will be just where decline begins, i.e. 40. But all this is according to Irenaeus. We have no reason to suppose that Papias intended any exact divisions. To make up the number of seven he was obliged to make four periods before aetas perfecta, but we need not suppose that he meant them to be exact decades. It is sufficient to realize that any age between 30 and 40 could be represented as perfect maturity of manhood. 
practically obliged to use pueritia, and to find another word such as adulescentia for the next stage.

$c$. Thus the two systems are undoubtedly identical. They apply to Christ four stages of growth and one of perfection, besides birth and death. The system is not a popular or heathen one, but was obviously invented to suit the life of Christ.

d. Clearly Victorinus and Irenaeus are dependent on a common source. We have already seen that the source of Irenaeus is as good as stated by him to be the book of Papias. We thus gain a singular confirmation of our attribution to Papias of the longer passage of Victorinus from which this sentence is taken.

e. Irenaeus is a bad witness to the original form of the passage, for in the first place he has not quoted the seven stages right off, and in the second place he has misunderstood it.

$f$. Victorinus on the contrary gives the passage very shortly but clearly, and emphasizes the number seven. Now the whole system was obviously made up for the sake of that mystical number, and in order to shew that Christ sanctified all that is perfect in humanity, and that His humanity was perfect. It would seem a priori likely, therefore, that Victorinus has preserved the passage in its original setting, as one out of a number of mystical sevens, and as a part of the application to Christ of the seven days of creation which Anastasius of Mount Sinai knew Papias to have elaborated. ${ }^{1}$

I conclude, then, that Victorinus and Irenaeus have used the same passage of Papias. Irenaeus has misrepresented it; Victorinus has given it faithfully. If our conjecture about mens parva was justified, we may even believe that he has given an almost verbal rendering from the Greek. Further, if that conjecture stands, the passage is a concoction of Papias's own 'little mind', and he did not base it on tradition. And if this be so, we need only suppose that Hippolytus and Irenaeus were misled by the prologue to believe that all Papias's statements rested on the witness of the Presbyters. It was not unnecessary for Eusebius to draw attention to the fact that Papias himself spoke slightingly of his own assertions, and did not set them all up as Apostolic traditions.

It is easy to see how Irenaeus was led into an erroneous interpretation '

${ }^{1}$ Humantatem suam consummat, 'He makes perfect His human nature by these stages,' reminds us of St Irenaeus's 'deinde et usque ad mortem pervenit, ut sit "primogenitus ex mortuis", "ipse primatum tenens in omnibus", "princeps vitae", prior omnium, et plaecedens omnes'; where it is meant that Christ became first of all men, young or old. Similarly Irenaeus says elsewhere (iii 18, 7 ): 'Quapropter et per omnem venit aetatem, omnibus restituens eam quae est ad Deum communionem.' 
of Papias's harmless mysticism, by his desire to go as far as he could against the heretics, and by his mistaken explanation of 'Thou art not yet fifty years old'. I infer from all this argument that Papias was more credible than Irenaeus, though probably less interesting, and that there is no reason to suppose that 'the Presbyters' were a 'Gesellschaft betrogener Betrüger'.'

John Chapman.

1 So Corsen called them, Monarchianische Prologe, T.U. xv 4 p. rog.

\section{Additional note on the date of the birth of St Irenaeus.}

St Irenaeus tells us (iii 3,3 ) that he had seen St Polycarp $\dot{\epsilon} \nu \tau \hat{\eta} \pi \rho \dot{t} \tau \eta \dot{\eta} \eta \hat{\omega} \nu$

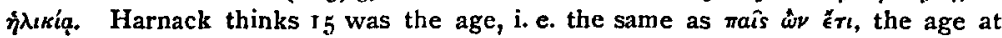
which Irenaeus saw Florinus, then a courtier, in company with Polycarp. Prof Gwatkin rightly pointed out that this was too young for the word inderia, and preferred 20 (Contemp. Rev. I 897, pp. $221-226$ ). Indeed $\eta^{\lambda} \iota \iota x i$, when used absolutely for an age, means manhood, military service. But we have seen that Irenaeus had defined it only a few. pages back as beginning at 30 ! Here $\pi \rho \dot{\omega} \tau \eta$

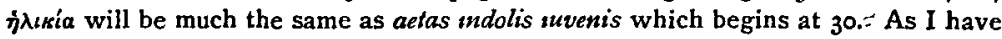
shewn in the text, Irenaeus certainly means that he was over 30 at the end of his intercourse with Polycarp. He implies 'I was not a mere boy, I was in my early manhood, though it was long ago'.

Now the death of Polycarp is usually placed in 155. (I myself argued in Revue Bénéd. 1902, 145-1 49, that we must date it 166, if Schmid's chronology of Aristides was right. But Ramsay and others are so positive that Schmid is wrong, that I presume we must follow Waddington.) Therefore Irenaeus was born before 125 , indeed hardly later than 120 ; for there is no reason to suppose that he was in Asia at the time of Polycarp's martyrdom, and tradition represents him as engaged in lecturing at Rome at that time. If we placed his birth $c$. 140 with Harnack, he would have been only 37 when he became bishop, and only about $44^{\circ}$ when he published his great work! Yet he evidently writes as an old man, giving his recollections of a past now in danger of being forgotten.

On the other hand he says that the Apocalypse was written in Domitian's reign,

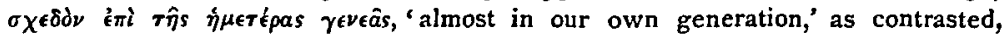
I suppose, with such ancient writings as the Synoptic Gospels and Pauline Epistles (c. 50-70). I hardly think a man born under Hadrian (II7-138) would speak thus, but one born in the last years of Trajan (97-117) would naturally do so. I therefore take it that Zahn's date, ${ }_{115}$, twerity years after the Apocalypse, is not far wrong (Forschungen vi 29 note). If Irenaeus was born in 116 he. was a 'boy' of $\mathrm{I}_{4}$ if Florinus came with Hadrian in 129 to Smyrna (2b. 30); he was 39 at the death of Polycarp, whom he may have seen for the last time some years before; he was $6 \mathrm{I}$ when he became bishop, a probable age; and he was about 68 when he published his great work, c. I $S_{4}$, after many years of work at it. :If Florinus was born in I Io or II 2 , he might live to be excommunicated by Victor (IgI), though Zahn may possibly be right that he was already dead when Victor wrote. 